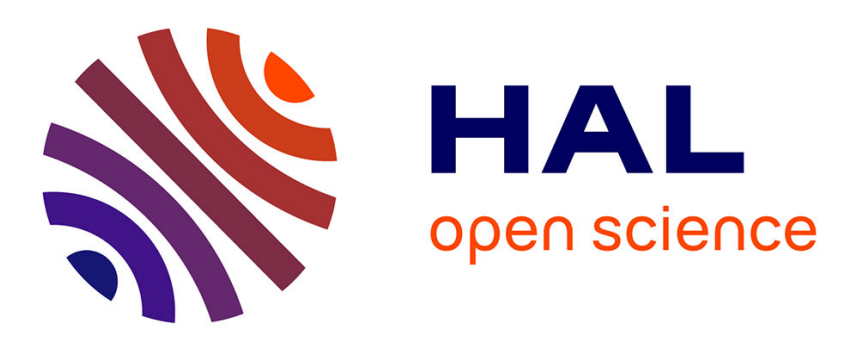

\title{
English and French Modes of Regulation of the Education System : a comparison
}

Denis Meuret, Marie Duru-Bellat

\section{To cite this version:}

Denis Meuret, Marie Duru-Bellat. English and French Modes of Regulation of the Education System : a comparison. Comparative Education, 2003, 39 (4), pp.463-477. halshs-00004973

\section{HAL Id: halshs-00004973 \\ https://shs.hal.science/halshs-00004973}

Submitted on 20 Apr 2018

HAL is a multi-disciplinary open access archive for the deposit and dissemination of scientific research documents, whether they are published or not. The documents may come from teaching and research institutions in France or abroad, or from public or private research centers.
L'archive ouverte pluridisciplinaire HAL, est destinée au dépôt et à la diffusion de documents scientifiques de niveau recherche, publiés ou non, émanant des établissements d'enseignement et de recherche français ou étrangers, des laboratoires publics ou privés. 


\title{
English and French Modes of Regulation of the Education System: a comparison
}

\author{
DENIS MEURET \& MARIE DURU-BELLAT
}

\author{
Published in Comparative Education Volume 39 No. 4 November 2003 pp. 463-477 \\ Correspondence to: Marie Duru-Bellat, University of Burgondy, IREDU-CNRS, BP 26513. 21065 Dijon cedex France. \\ Email: marie.duru-bellat@wanadoo.fr
}

\begin{abstract}
This paper describes English and French modes of regulation of the educational system, stressing the contrast between them (regulation by process versus regulation by outcomes), while their goals and organisation prove rather more convergent over the last 30 years. It tries to assess the correspondence between those two ways of operating and what we know about the functioning of organisations like schools. From that point of view, the French system fits the economic theory of organisation less well than the English one, so that some contradictions and tensions are predictable. Last, it looks for some relationship with indicators of effectiveness, equity and social satisfaction towards school in the two countries. No clear relationship emerges at the present time, but the analysis may help predict some problems that lie ahead.
\end{abstract}

Thirty years ago, the English and French educational systems were considered, and were to some extent as opposite as possible. The English system was devoted to the personal and social development of children while the French was devoted to teaching a strong, academically oriented national curriculum. The English system was driven from Local Educational Authorities (LEAs), while the French was driven from the Centre (the Ministry for National Education). The very culture of the teachers strongly reflected these differences. While French teachers were proud to teach every pupil the same way, whatever their social or cultural background, English teachers considered their main professional responsibility to 'start building up closeness to the child first' (a teacher, quoted in Osborn et al., 1997), and to care about his self-esteem and self-confidence.

To a large extent, reforms which have been implemented in the last 30 years in both countries have made the two systems converge. In England, a National Curriculum for the main subjects and assessments at key-stages resulted in a more academically-focused system and also a more centralised one. In France, conversely, the National Curriculum was made more flexible, more concern for social development was introduced, adaptation to the children's needs was advocated. As a result, a large number of teachers in both countries have felt, for opposite reasons, that their professional dignity was being attacked. English teachers felt that they were losing their autonomy regarding the objectives of teaching (both level and nature), and that their pupils' needs were being sacrificed to the requisites of the economy. French teachers thought they were being turned into social workers.

The organisation of the French education system was reformed during the 1980s: French middle schools came to be truly comprehensive, and more autonomy was given to schools in both countries. France introduced in 1989 the 'Projets d'établissements' which were 
very close to the English 'School development plans'. The rhetoric of educational government also came closer, with words like 'evaluation', 'team work' and 'quality' being used on both sides of the channel, as everywhere in Europe.

This convergence of the goals, ethos and organisation of the two systems makes more striking the differences which continue to exist regarding the way they are regulated. By regulation we mean the procedures which an authority uses to orient the actions and behaviour of its agents. We endorse here the idea that the nature and the strength of regulation matter more to understanding the functioning of an educational system than its degree of centralisation (Broadfoot, 2000). Tradition alone cannot explain these differences, since, in both countries, regulation also has been deeply affected by reforms during these last thirty years.

We will describe first the two systems of regulation. Then, we will try to make a judgement about the two systems, according to what we may estimate to be their effects, to their internal coherence and also to their correspondence with what we know about the functioning of organisations like schools.

As the English system is often considered as the purest example of a 'liberal' model which is typical of the Anglo-Saxon tradition (Davies \& Guppy, 1997) and is also most in evidence in European, including Latin, countries (e.g. Barroso, 2000, for Portugal), the underlying question for French researchers is to explore whether their country has succeeded in proposing an alternative model, or rather a successful adaptation of the 'liberal' model to the French context — what Schriewer (1997) would call its 'nativisation'—, or whether we have destroyed our former system of regulation without being able to replace it by a stable one.

\section{The Two Systems of Regulation}

In England, the Labour Prime Minister, James Callaghan first declared in 1976 that a great reform of the educational system was necessary. But the reform was subsequently made by the Tories, with Mrs Thatcher at the head of the government. The reform was announced as a revolution, based on the values of responsibility and effectiveness, and it was harshly debated (Edwards \& Whitty, 1994). Arguments of the opponents were that it would result in fewer resources for education, a narrowing of the curriculum, a lowering of teachers' professional autonomy and morale, and, above all, more segregation and inequity. However, Broadfoot (1999, 2000) makes clear that the formal system of accountability by results which followed this 'revolution', opposed as it may have been to the preceding system of regulation, was also to some extent in line with the tradition of informal accountability to children and to parents, which was and still is an important aspect of the ethos of English teachers.

In France, the debate was not so harsh as in England and it was not conducted by the political parties. The reform was made progressively, under the appearance of technical measures which were alleged to be necessary: globalisation of the world economy-a sad but inescapable reality-made it necessary to open secondary schooling to a greater proportion of young people, and reform was necessary to face the newly enrolled population of students. As a consequence, Dubet and Duru-Bellat (2000) could write: 'the reform was made slantwise, with nostalgia', and not with the open opposition of values (responsibility vs equity) which could be observed in England. For instance, in France a zoning procedure exists, which means that students attend the local public school to which they are assigned by local education authorities based on their place of residence. When this procedure was made more flexible (1984), it was presented as a temporary experiment, no law or even national administrative regulation detailed the new rules, and the rectorats were free to implement the 'experiment' as they wished. Both the governments of the Left 
(1981-1986; 1988-1993), and the Right (1986-1988; 1993-1997) used this low-key policy. The only Minister who tried a more frontal way (Allègre, 1997-2000) had to resign under the pressure of an alliance of the teachers' trade-unions, the intellectuels and the media.

To describe the two systems of regulation, it is convenient to distinguish the supply side of regulation from its demand side. The former refers to the different types of schools and the way the administration ensures that they effectively pursue the goals they are intended to pursue. The latter refers to the way users-parents or students-are allowed to influence schools. On both sides, the concrete way that regulation is actually effected must be taken into account, along with the formal way it is meant to operate.

\section{Supply Side}

In both countries, the autonomy of schools has-perhaps surprisingly-increased, but far more strongly in England. In England about $60 \%$ of the decisions which affect secondary schools are taken at the school level, as against only 30\% in France. French schools have some autonomy for the organisation of instruction, constrained for the most part by a framework decided at a superior level, but they have no autonomy at all regarding staff management, including the hiring and dismissing teachers (OECD, 1998).

On the other hand, English schools are subject to strong external supervision. Schools are inspected by OfSTED every six years, and the school has to provide a plan in answer to the Inspectors' criticisms. The pupils' achievement at the key stage tests are annually monitored by LEAs. This supervision may result in some help, but also in some harmful consequences: schools may be put under 'special measures', or they may even be closed. This occurs inside a rather strong culture of school self-evaluation, which according to OfSTED is reinforced by inspection and, according to most researchers, is harmed by it (e.g. Saunders, 1999; MacBeath, 1999). The Labour government has proposed a new conception of school autonomy which is expressed by the formula: 'Intervention of the State in the life of schools will be in inverse proportion to their success' [1].

In France, teachers are inspected, but schools are not. There have in some places been experiments of school audits (Demailly et al., 1998) but in all cases, this was conceived as a help to a school, and not as pressure on it. It remains the school's decision whether or not to take account of what the audit has shown. Some official commissions have called for more demanding forms of audit, but these have not been tried (Dubet et al., 2000). In the same way, indicators are provided to each school, which allow it to compare its intake, resources, policies and results - including some value added indicators, which compare for instance the expected rate of success in the baccalauréat to the actual one-with those of other schools, but it is up to the school whether or not to use these indicators (Meuret, 1986; Emin, 1996).

Since the education act of 1989 ('loi d'orientation'), each French school is required to produce every four years a 'Projet d'établissement'. The rectorat-the regional administration of the Ministry of education-looks at these projects, and may reject some of them if they are not in accordance with the national policy, but it is not interested in their outcomes, in terms of student achievement or anything else (Meuret et al., 2000).

\section{Demand Side}

According to a classic distinction, users may have an influence on schools either through 'voice' (participation in school life and on school boards) or through 'exit' (choice of another school).

Traditionally, it is easier for English parents to be heard in schools than for French ones. 
Until recently, it was still the case, at least as far as primary schools were concerned (Broadfoot \& Osborn, 1993) [2]. Parents nowadays have more opportunity than before to express their advice on school life, be it informally or through the participation in the school's 'conseil d'administration' or 'conseils de classes'. Also, they are more strongly involved in the decisions concerning their child's allocation to the different tracks (vocational or general) when the comprehensive stage comes to an end. But, actually, parents are often unable to have any influence in the different 'conseils'. The fact that, for instance, in England inspectors meet parents in the absence of any school staff is certainly not possible in France.

A pupil's admission to a particular school depends in France on where he or she lives, while in England it is formally a matter of choice. However, the difference is perhaps not so striking. In England, parents may ask for whatever school they want, and, provided that the school is not full, they must be given satisfaction by the LEA. For some types of school, (former Grant Maintained, Voluntary Aided) however, admissions are determined at school level. In France, a child is assigned to a school, but, in some places where the 'carte scolaire' (school zoning) has been loosened, parents may ask for a 'derogation' (waiver), which is given according to criteria that are often the same as those used in England for or by oversubscribed schools-for example, the presence of siblings in the school, medical or social need [3] (West \& Ingram, 2001). In England, information on school performance is provided to parents through League Tables and through OFSTED reports. In France, three indicators are published about high schools (lycées), one being a value added type. No indicator is published about middle schools.

\section{Regulation by Process versus Regulation by Outcomes}

At this point, the reader, even if he/she is not an advocate of the strong pressure which is put on schools in England, both from the users and the State, may ask: how does the French Ministry ensure that the flexibility which was introduced is used for what it considers to be the best interest of the students and the country?

The answer is: regulation by process. To English eyes, this kind of regulation is a traditional feature of the French system. However, while its ancient form aimed at ensuringmore or less successfully - that each individual teacher taught what and how he was supposed to do-and when-, the current one is persuasive more than prescriptive, school-centred more than teacher-centred, procedural rather than substantive. For instance, the Ministry exerts pressure on schools to adopt new patterns of schooling which are supposed to be relevant and efficient (études surveillées, travaux personnels encadrés, parcours diversifiés, etc.). The precise content of these patterns has to be decided by teachers themselves at the school level through prescribed procedures, but, most often, they require the cooperation of several teachers, and have to proceed from a diagnosis of the students' needs. Some teachers who personally support these patterns are hired on a part-time basis by the rectorats to help and encourage schools to implement them. School-heads are de facto appraised by the rectorat according to their ability to persuade the teachers to implement them. At a more general level, the scrutiny of the 'Projets d'établissements' by the rectorat comes under the same logic. Of course, this approach to regulation faces the risk which is pointed out by Ravitch (1999) concerning the USA, that: 'Having a well named program is more important than having an effective program'.

\section{An Assessment}

Here, we will try first to investigate the 'theoretical legitimacy' of both regulation systems, then to look at the contradictions and tensions they may contain; lastly, we will search for 
what we may know about their effects on the effectiveness, equity and political acceptance of the educational system.

\section{Theoretical Legitimacy}

To what extent do the two regulation frameworks fit what theories of organisation tell us about schools? We will investigate first economic then sociological theories.

Modern economic theory of organisations (see Milgrom \& Roberts, 1992), suggests that regulation has to ensure that agents (here, school staff) effectively pursue the goals that the Principal (here, the elected government) sets for the organisation. This is unlikely to be achieved naturally since the goals of both parties may not be the same-the interest of most agents is not to work hard [4] — and since agents benefit from an 'informational asymmetry', which is especially important in the case of teachers: they (and they alone) know what they are doing and the conditions of their work. This 'informational asymmetry' gives space to the phenomenon of 'moral hazard', when the agent pursues its own interest instead of the goals of the organisation. This may take two forms: goal displacement-a form of which is the confusion between means and end-or under-investment in the job.

Policies aimed at reducing moral hazard generally make goals as clear and as coherent as possible, organise internal competition inside the system, and attribute supervision to delegates of the Principal close to the agents, in order to monitor their work and to improve co-ordination, make sure that people who take decisions have the relevant information and propose incentives to work, some positive, some negative. We use this canvas to look at both systems of regulation in Table I.

As can be seen from Table I, the French regulation system does not appear to fit very well with the economic model of regulation. In fact, the new regulation gives more autonomy to teachers, with weak control by the school head, the administration or the users.

Moreover, the processes which are 'strongly recommended' to schools have not, most of the time, been trialled and proved to be efficient before their implementation. This is not an abstract concern, since many of the methods advocated, especially during teachers' initial training (differentiated teaching, individualisation) have been shown, actually, to be ineffective or to further inequalities between the more and the less able pupils (see Duru-Bellat, 1996, on differentiation; Crahay, 2000, on individualisation). However, some new policies are explicitly designed as experimental and their generalisation subordinated to a positive evaluation, e.g. a policy of group size reduction for the teaching of reading decided in June 2002. This seems to indicate that the ministry is giving itself adequate tools for a centralised management of educational policies, which also occurs in England. However a difference between the two countries is that in France this evolution is limited to the centralised decisions, while the so called 'Evidence based teaching' movement in England is valid also at the school level, that is, teachers are also encouraged to ground their decisions on evidence (Oakley, 2002).

If the theory is right, this would result in a less favourable evolution in France than in England, regarding effectiveness, and also regarding equity since the economic model is valid for whatever objective, including that of ensuring that staff and schools try hard to improve the achievement of the weakest, or of the more disadvantaged pupils. The fact that the performance of the top $10 \%$ in France is twice that of the $10 \%$ weakest at the age of eight (MEN-NI 01-35), but three times greater at the age of 11 (MEN-NI 01-36), is not a very good sign, even if we do not know how important was this gap before the reforms.

In fact, while the evolution of the English system of regulation is more or less in accordance with the requirements of the economic theory of organisations, the French evolution has been driven by other models of organisation, which are known as the 'Human Relations' approach or the 'Organic Model’ (Scheerens \& Bosker, 1997). 
TABLE I. English and French regulation framework from an economic point of view

\begin{tabular}{ll}
\hline England & France \\
\hline
\end{tabular}

Make goals more clear

Tradition of especially unobservable goals, but Standards and National Curriculum strongly reduced uncertainty.

Increase competition

School choice.

More diverse schools, but those schools which were supposed to bring new models of schooling (GM, CTC) turned very traditional and enhanced the hierarchy among schools more than the diversification of supply (Edwards \& Whitty, 1997).

Supervision at the local level, co-ordination

Local management of schools resulted in a stronger role of the school head, and of the heads of departments.

School heads are now said to be interested in management and marketing more than in education (Gewirtz et al., 1995)

Provide information to the staff

Panda* report allows the comparison of performances with those of 'similar' schools.

About a third of English schools decide themselves to be involved in more sophisticated indicator systems.
Tradition of national curriculum, national examinations and academic orientation, but reform resulted in more diversity in the goals, and more flexibility in the National Curriculum.

Possibility of exemption from the 'carte scolaire' in some areas, but a recent administrative text declares 'an absolute interdiction of competition among schools' (Circulaire 98-263), which appears to be impossible to implement, according to which exists even in areas where the Carte scolaire has not been made more flexible (Broccholichi \& van Zanten, 1997).

A slightly stronger role for the school head; no department.

Training and recruitment of school heads has been improved.

The 'projets d'établissement' are supposed to enhance co-ordination, but they are often formal (IGAEN, 1999). The diversity of teachers practices and attitudes was shown not to be reduced by the fact that they work in the same school (Grisay, 1993).

Some attempts to organise co-ordination among the schools of a same area ('Bassins de formation').

Indicators on the school are provided by the administration, but they are not often used.

Some schools calculate their own indicators, propose questionnaires to their pupils. This did not occur in the past, but whether they result in decisions is more dubious.

National evaluations at the beginning of the school year at age 7 and 11, allow teachers a more accurate diagnosis on their pupil needs. These evaluations are generally used and appreciated by teachers (Alluin et al., 1996).

More frequent assessment of students is planned. 
TABLE I. English and French regulation framework from an economic point of view—continued

\begin{tabular}{|c|c|c|}
\hline & England & France \\
\hline \multicolumn{3}{|l|}{ Incentives to work } \\
\hline Salary increase ** & $\begin{array}{l}\text { Merit pay has been introduced in order } \\
\text { to retain best teachers. }\end{array}$ & $\begin{array}{l}\text { The level of diploma necessary to become } \\
\text { a primary teacher has been increased, as } \\
\text { well as the salary of this staff. }\end{array}$ \\
\hline \multirow[t]{2}{*}{ Symbolic awards } & $\begin{array}{l}\text { Publication of League tables and } \\
\text { Inspection reports has consequences for } \\
\text { the reputation of schools. League Tables }\end{array}$ & $\begin{array}{l}\text { Teachers who are drawn out of the } \\
\text { classrooms to work for the rectorat feel } \\
\text { honoured. }\end{array}$ \\
\hline & $\begin{array}{l}\text { are accused of reflecting more the intake of } \\
\text { the schools than the quality of the work } \\
\text { of its staff and therefore of distributing } \\
\text { unfair awards. }\end{array}$ & $\begin{array}{l}\text { Publication of the performances of high } \\
\text { schools has consequences on their } \\
\text { reputation. }\end{array}$ \\
\hline \multirow[t]{2}{*}{$\begin{array}{l}\text { Negative consequences } \\
\text { of failure }\end{array}$} & $\begin{array}{l}\text { Only a small percentage of very } \\
\text { ineffective teachers remain in place } \\
\text { without having improved (Wragg, } \\
\text { 1999). }\end{array}$ & $\begin{array}{l}\text { Parents and heads heavily complain that } \\
\text { 'nothing can be done' against very } \\
\text { ineffective teachers. }\end{array}$ \\
\hline & $\begin{array}{l}\text { Ineffective schools are eligible for 'fresh } \\
\text { start' or 'special measures'. Opinions on } \\
\text { the effectiveness of this procedure are } \\
\text { mixed (Stoll \& Myers, 1997) }\end{array}$ & $\begin{array}{l}\text { No help or pressure on low performing } \\
\text { schools, except in one district (Créteil). }\end{array}$ \\
\hline \multicolumn{3}{|l|}{ Job enrichment } \\
\hline & $\begin{array}{l}\text { Evolution of the task is presented as a } \\
\text { move towards a more modern form of } \\
\text { professionality. }\end{array}$ & $\begin{array}{l}\text { The tasks of the teachers became more } \\
\text { flexible and diverse. More adaptation to } \\
\text { the pupils' needs is advocated. Team work } \\
\text { is praised. }\end{array}$ \\
\hline & $\begin{array}{l}\text { 'Most headteachers would not } \\
\text { relinquish the authority that has been }\end{array}$ & More information is available. \\
\hline & $\begin{array}{l}\text { given to them under LMS' (Finkelstein } \\
\text { \& Grubb, 2000). }\end{array}$ & $\begin{array}{l}\text { Not all secondary teachers perceive this as } \\
\text { an enrichment, some perceive it as an } \\
\text { evolution towards a role of 'social worker' }\end{array}$ \\
\hline & $\begin{array}{l}\text { The opinion of (primary) teachers } \\
\text { regarding whether reforms have changed } \\
\text { things for the better or the worse are } \\
\text { very close in both countries (Osborn et } \\
\text { al., 1997) }\end{array}$ & (Dubet et al., 2000). \\
\hline
\end{tabular}

*Panda (Performance and Assessment) report provides each school with data relating to the performance of their students as the last key stage tests. Schools can then compare these performances with those of comparable schools.

**The 'efficiency salary' is the smaller salary which discourages cheating, among other reasons because it is superior to that of the market and therefore agents fear being dismissed. When the agents cannot be dismissed, like in the French educational system, this fear does not exist, but other symbolic mechanisms may perhaps play a role.

In the Human Relations approach, the eye of the organisation analyst is explicitly focused inwards instead of on 'outcomes' as in the economic approach. This model criticises bureaucracy as being 'rigid', and says the key of effectiveness lies in teacher motivation, well-being, morale, autonomy and in their capacity to adapt collectively to circumstances-in short, in human resources development. It is in line with the strong autonomy of professionals described in the 'professional bureaucracy' (Mintzberg, 1973) and with the model of schools proposed by Bidwell (1965) or Weick (1976). As a consequence, this model of regulation, as can be seen in Table I, does not address the shortcomings that Mintzberg describes as those of the professional bureaucracy: difficulty with solving the problem of ineffective agents, difficulty with coping with the problems which are not perceived as such by the professionals, lack of co-ordination, etc. 
According to the organic model, as described by Scheerens and Bosker (1997), 'organisations can be compared to biological systems which adapt to their environment. Organisations must be flexible, namely to assure themselves of essential resources and other inputs'. In the discourse of the French reform, 'environment' is seen as the increasing diversity of pupils, that is, of the social environment, to which the school and the teachers have to adapt permanently. The purpose of the 'projet d'établissement' is to encourage schools to such an adaptation, but no incentives are given for the schools to implement truly adapted and effective 'projets'. The result is thus often only a formal use of this tool.

\section{Contradictions and Tensions}

The fact that the English model fits relatively well with the economic model does not mean that it is immune from tensions. The main one is that schools may be under divergent pressures from the market and the LEAs, parents being more interested in their children's well-being and a culture of caring, and the administration entirely devoted to the academic effectiveness of the whole system. Scheerens and Bosker (1997, p. 268) develop this opposition between a 'restructuring' model of schooling regulated by a market, oriented towards the users' demands for 'preparation for real life' and a model of 'school effectiveness' regulated by an output-oriented control by the higher administrative levels, directed towards achievement in basic school subjects. In fact, it appears that this tension is reduced by the fact that parents, and specially the 'skilled choosers' (Gewirtz et al., 1995), are also interested in academic effectiveness. But it does exist since parents choose schools not only according to their effectiveness but also in terms of other criteria, some of them being detrimental to the effectiveness of the whole system, like social matching (Hunter, 1991). A market orientation may also be detrimental to effectiveness if it results in a stronger academic segregation in classrooms and schools (see Duru-Bellat \& Mingat, 1997, for a study of classrooms academic heterogeneity in French middle schools [5]).

Another tension is between the strong autonomy of schools regarding resources and staff management, and the strong pressure of accountability. It is now admitted that school-based management without accountability does not often produce the desired outcomes (see Murphy \& Beck, 1995, for a discussion of this topic for the US). However, the quality of the accountability framework is obviously crucial given that doubts have been expressed about the technical validity of Inspector's judgements in England (Fitz-Gibbon \& Stephenson, 1996). It is also difficult to understand that a system devoted to academic effectiveness publishes raw indicators like those of the League Tables, and not Value Added indicatorsalthough the 'Autumn package' now includes some value added type indicators at the school level. Even so some researchers point to the technical limitations of the latter (Goldstein, 1997), as well as the difficulty of them being understood by parents.

Moreover, the English Ministry recently implemented the very centralised 'National literacy and numeracy strategies', which, although they seem to be endorsed by teachers, according to OfSTED (2001) are at odds with the policy of school autonomy.

Another tension in this model could be that the strong pressure on teachers may dissuade graduates from joining the profession, as the difficulty with recruiting teachers, which is, for the time being, stronger in England than in France, seems to show [6]. However, it appears that only a small proportion of primary teachers, between 5 and $10 \%$, no more in England than in France, think that the reforms have changed things for the worse [7] (Osborn et al., 1997).

Contradictions and tensions in the French model of regulations are of a different nature. They can be interpreted as the result of the weakness of the theoretical background of the 
French regulation reforms. They are linked to the weakness of its political government. Both resulted in several inconsistencies.

Some contradictions occur between the presence of small areas of accountability or choice in a system that is generally reluctant to yield to these. Information on the effectiveness of high schools is published while competition among schools is, as we saw, forbidden. There are serious consequences, given the fact that choice is tolerated to a limited extent through the procedure of 'dérogations', but is not overtly organised. This tends to favour those parents who have the best knowledge of how the system really works - that is middle-class parents and the teachers-and is in the hands of agents who are convinced that most of the applications are grounded on reasons contrary to the common good (Meuret et al., 2001). In England, the overt nature of the school choice procedure allows for explicit measures to protect against its drawbacks like code of practices or schools adjudicators (West \& Ingram, 2001), which cannot exist in France.

Other tensions are inherent in the mode of regulation by process. One example is the control of the 'projets d'établissements'. Either the rectorats control, as they did some years ago, the scope of the projets, and schools complain, rightly, that this is contrary to their autonomy, or they just look at their legal validity, and they have no way to influence schools. A recent agreement (2002) between the government and trade-unions opens the possibility of 'lettres de mission' (a form of contract) between the administration and each head teacher regarding the objectives his or her school has to reach within four years. But it is too early to know if this will really be implemented. Another example is the fact that, as teachers complain in England about the contradiction between autonomy and accountability, they complain in France that they 'are told how to teach' by the regulation process. Therefore, some of them oppose the new 'pedagogical forms' (e.g. the 'itinéraires de découverte' in middle schools) and the Ministry sometimes has to accept that the teachers who do not want to implement them may be allowed not to do so. Still another one is the difficulty of recruiting school leaders (Blanchet, 2000), which may be attributed to their uncomfortable situation with no other resource than their personal powers of persuasion to ensure that teachers adopt the pedagogical forms recommended by the rectorat and the ministry.

These contradictions, along with the fact that parents' capacity to influenceschools has been only slightly increased, may lead to frustrations among users [8]. This tension will be very hard to solve, for the role of parents in France is limited by the fundamental nature of the educational system. Schooling in France has long been regarded as a process of freeing the individual through enlightenment and reason, but also as a process of the domestication of irrationality, passions, and egoism which are, as Rousseau taught us, characteristics of man in the spontaneous course of the process of civilisation. So the French school is faced with reorienting this course. To a certain extent, it can be said that, in Anglo-Saxon countries, schools are there to help children to perpetuate the world (Arendt, 1993), while it has in France to institute the world, or at least the République, again and again for each generation (Meuret, 1998). This is a fundamental reason to give parents or students no right to influence the school (Debray, 1998). As a consequence, the (few) rights parents have acquired are perceived as concessions to modernity, but not as fundamentally right. For this reason also, we may suspect that the failure of a school is more shaming in France than in other countries.

Other tensions appear among French teachers themselves. The independence they enjoy under the new regulation, combined with the fact that they are reluctant to adopt the more collective mode of work which is proposed, result in a kind of loneliness. Some remain strong supporters of the old professional model while others do accept the new approach. In the absence of any clear indication coming from the political level, this results in some anomie among teachers. 
TABLE II. Proportion of the population of 25-34 years (45-54 years) in 1998 having completed secondary and university education

\begin{tabular}{lccccc}
\hline & \multicolumn{2}{c}{$\begin{array}{c}\text { Proportion having completed } \\
\text { secondary education }\end{array}$} & & \multicolumn{2}{c}{$\begin{array}{c}\text { Proportion having passed a } \\
\text { university degree }\end{array}$} \\
\cline { 2 - 3 } \cline { 5 - 6 } $25-34$ years old & $45-54$ & & $25-34$ & $45-54$ \\
\hline United Kingdom & $66 \%$ & $60 \%$ & & $19 \%$ & $16 \%$ \\
France & $76 \%$ & $57 \%$ & & $15 \%$ & $10 \%$ \\
\hline
\end{tabular}

Source: OECD (2001), pp. 50-51.

\section{Effects on Effectiveness, Equity and Satisfaction}

We lack data to compare adequately the effects of both modes of regulation on the effectiveness, equity or social attitudes towards school. However, we may try to use the few data we have. We will look first at effectiveness, then at equity, then at the satisfaction of users.

France spends a far greater part of its wealth on education than England: 6.5\% of the domestic product is spent on initial training, compared with only 4.9\% in England (OECD, 2002, p. 196).

In the last quarter of the century both systems have succeeded in opening secondary schooling to a greater proportion of the population, but this evolution was more pronounced in France than in England, as is shown in Table II by the difference between the two populations. However, the growth of the proportion of the population with access to tertiary education has nearly ceased in France since 1995, while it grew significantly during that period in England (OECD, 2001b, p. 167).

Regarding the knowledge and skills of pupils, we may use the international comparisons of IEA and of OECD (PISA). For our purposes, we need a comparison between performances before and after the wave of reforms. Of course, it is difficult to link the evolution of educational attainment to any precise policies (Gorard \& Taylor, 2002). However, it seems difficult to ignore them. As England did not participate in the IEA reading literacy study (1990) we are limited to mathematics. We have four studies for maths with the Second (1982, cf. Robitaille \& Garden, 1989) and Third (1995, cf. Harmon et al., 1997) IEA international studies in mathematics, with the IAEP study (1990, cf. Lapointe et al., 1989) and with the PISA study (2000, cf. OECD, 2001a). The IEA studies assessed pupils enrolled at grade 8 . Their results cannot be directly compared since they used different tests. PISA assessed 15-year-old students, again with other tests. However, this does not prevent us from making some comparisons between the relative situations of England and France.

What Table III shows is that while the two countries were on a par in the 1964 study, France outperformed England in the three following studies, and that the reverse is true for the last one. This observation would be in line with the predictions we derived from the economic theory of organisations. However, the skills measured in PISA are less directly related to the curriculum than in TIMSS. Also, the IEA studies tested grade eight students which is more favourable to France [9] — a country with a high rate of class repetition - than PISA, which tested an older age group. In both countries, according to the available national longitudinal studies, performance in maths has increased at grade eight, at least at the end of our period (MEN-DEP, 1996). ForEngland, education and training statistics (DfES, 1999) shows, for 1994-1999, a greater proportion of students reaching the expected level at the third key stage. However, the comparison in England of the results on the same TIMSS test between 1995 and 1999, shows no improvement of the mean score in maths (OECD, 2001b). 
TABLE III. Achievement results in Maths from three international studies in England and France

\begin{tabular}{lcccc}
\hline & SIMSS & IAEP & TIMSS & PISA \\
\hline Date of observation & 1982 & 1990 & 1995 & 2000 \\
Population England & Grade $8 *$ & Grade 8 & Grade 8 & 15-year-old students \\
& 48 & 61 & $506(2.6)$ & $529(2.5)$ \\
France & 53 & 64 & $538(2.9)$ & $517(2.7)$ \\
\hline
\end{tabular}

*For the first three studies, the true definition of the population is: the grade in which the modal number of students had attained the age of 13-13-11 in the middle of the school year. This resulted in grade 8 in England and 'quatrième' in France.

Source: For 1982 and 1990, Reynolds \& Farrell (1996); for 1995, Boston College, TIMSS report (Beaton et al., 1997). For 2000, OECD (2001a). For 1982 and 1990, achievement is expressed in percent of items correct; for 1995 and 200 it is an IRT score standardised for an international mean of 500 and a standard deviation of 100 . For that reason it is only possible to compare the relative position of France and England between the first two columns and the last two.

So we cannot say that the theory which predicts a more positive trend in England than in France is verified. A cautious conclusion is that we have here imperfect comparisons, which have to be extended before a well-grounded judgement can be made.

Regarding equity, as it is measured by TIMSS (1995), we may notice that the performance of the weakest $5 \%$ of pupils is better in France than in England, and that the gap between the weakest $5 \%$ and the best $5 \%$ is lower in France (Harmon et al., 1997). In the PISA assessment, there is no significant difference between the two countries regarding these two indicators of equity [10]. Neither does the PISA study reveal any significant difference between the two countries regarding the relationship between the students' performance and socio-economic background.

An important aspect of equity is segregation in schools, be it academic (between the best and the weakest pupils) or social (between children of low and high social background). In both countries, reforms were suspected to increase social and academic segregation among schools. In fact, social segregation did not increase among French middle schools from 1993 to 2000, while academic segregation slightly increased (Trancart, 2003). In England, contrasting evidence exists on the topic. At the national level, social segregation has remained stable, and perhaps has even been reduced, during the period 1988-1998 (Gorard \& Fitz, 1998, 2000), while it has increased in recent years (Noden, 2000). However, these results seem to be compatible with the observation of a growing academic segregation in some local areas where there exists a greater possibility of choice (Gibson \& Asthana, 1999). The resultant segregation is also a social one.

In both countries, parental satisfaction with the educational system seems to have increased slightly, or at least not to have decreased.

In France, according to a recent poll (CSA, April 2001), most parents deem that the quality of teaching is good in primary education, but that this is no longer true of secondary education: only 56\% of parents find quality good or very good in middle schools, and $61 \%$ in high schools. However, from 1988, a date which is close to the implementation of most of the policies reviewed here, to 1996 the percentage of parents who think that 'teaching in France operates well' rose from 42-52\% (Deschamps, 1998).

In England, according to a MORI poll (2001) of adults over 18, satisfaction with school seems to be lower (38\% are satisfied with standards in education), but is on a positive trend: $33 \%$ in the same poll declared that standards in education had got better since 1997, while only $17 \%$ declared they had got worse. 
Of course, the results we use here do not allow for a precise diagnosis of the effects of both modes of regulation. What can be said, however, is that in neither country have the reforms led to a spectacular decrease in effectiveness, equity or adhesion to school, as some feared. The conclusion is also that the effects of regulation, if they exist, are probably small and affect the performance of the system only marginally (but on a long-term basis).

If no strong effect of the difference in regulation procedures can be discovered for the time being, and according to the available data, between the two countries, it may be relevant to end by asking the question of how both systems of regulation are likely to react to the trends that will affect the educational systems in the near future.

\section{Discussion: stability for the future?}

The main question in England concerns the way teachers will react if there is no real evidence of progress in what is the major objective of the reforms: to increase achievement in basic subjects. For instance, an OfSTED report (OfSTED, 2001) suggests that teachers were committed to the literacy strategy and were rewarded by students' progress, but also that this progress stopped in 2001 for reading. Another question concerns how the users demands will evolve, and if the contradiction with the objectives of the administration will grow, or remain at the current level.

In France, it may be possible to introduce progressively more administrative regulation by results (Joutard \& Thélot, 1999). We tend not to share this view.

Whatever their current level of user satisfaction, the main menace to existing modes of regulation will probably come from users (parents and students) because of two basic trends. First, education is becoming more and more a 'private good', with well-documented consequences on the life and professional careers of everybody. Although, for several reasons, education has to remain a public responsibility, one consequence of this trend is that users cannot be considered as in the traditional system: they will probably no longer accept not being protected from bad schools or ineffective teachers and not being listened to. France may use 'exit' or 'voice', but it is not clear if the 'voice' approach is likely to succeed without a frontal challenge to the traditional model itself. Second, the indignity which is attached to school failure remained bearable as long as the values and aims of school were competing with other values - indeed precisely those values which the traditional school was designed to fight. When all sectors of adult society (firms, families, media, etc.) share common values and accept more or less as their own the hierarchy which comes out of school, such failure becomes unacceptable.

We think that these trends will in future make it necessary to organise the regulation of the education system by results in order to avoid a wild and highly unequal education market. The comparison we have presented here shows that recent fundamental reforms are in line with the history and tradition of each of the educational systems. In France, regulation by results goes against the underlying model of French education and against its deepest roots. Consequently the 'modernist' framework, which supposes that 'modern' forms of pedagogy may be identified and will be implemented sooner or later if they are proposed to the actors, does not work. For that reason, we tend to think that France has not succeeded in inventing an alternative model to the English one, as Broadfoot (1999) [11] hoped. An optimistic view would suggest that the story has not come to its end and that France is still in position to invent such an alternative model. But what is certain, if our analysis is correct, is that France is facing more fundamental revisions than England, if it is to make its educational system more understandable and legitimate. 


\section{NOTES}

[1] It has to be stressed that this conception is to some extent the opposite of another one formulated in the USA, where the intervention of the State has to be limited to the implementation of patterns which have been proved to be efficient. All the patterns with no proved efficiency have to be decided at the level where they can most easily be given up, i.e. the school (Ravitch, 1999). In the first case the burden of the proof is on the school shoulders, in the second case it is on the government's.

[2] $71 \%$ of the primary teachers in England, versus $40 \%$ in France, agree that 'parents should have a say in what their children learn at school'; 67\% in England, versus 7\% in France feel that 'teachers should adapt their teaching to meet parents wishes' (Broadfoot \& Osborn, 1993, p. 100).

[3] Another criterion often exists, which is not among the ones which are allowed in England by the School Standard and Framework Act (1998): priority to the children of employees.

[4] Of course, some agents, in schools, are very dedicated to their work, and it is even possible that some of them are so in a way which is coherent with the principal goals, but the theory needs only the assumption that this is not the case of all agents.

[5] What the weakest pupils gain when attending a heterogeneous class is much more important (about twice) than what the brightest lose when attending such classes. So, heterogeneous classes result in more progress for the whole generation. Given that market favours ability grouping, through the strategies of the brightest pupils' parents, it will result, all things being equal, in a weaker average level and also in more inequalities between pupils.

[6] A poll by Goal (2001) shows teachers working 56 hours a week in England, according to their estimation, while another poll by MORI finds that $80 \%$ of graduates describe teaching as 'hard work' (MORI website).

[7] In England, 2\% in middle-class areas and 12.5\% in disadvantaged areas; in France, 5\% in disadvantaged areas and $12 \%$ in middle-class areas. The most frequent advice (about 55\%) is that it changed nothing or that teachers have mitigated feelings about the reform (Osborn et al., 1997, Table V, p. 387).

[8] We are not aware of the evolution of parents' opinion regarding their relation with teachers, but a 1997 poll indicates that $43 \%$ deem these relations are not satisfactory as against $48 \%$ who find them satisfactory (Deschamps, 1998).

[9] Mean age of the students in TIMSS was 14.3 for France and 14.0 for England.

[10] PISA report, Table 3.1 (OECD, 2001a).

[11] 'Indeed, it suggests the possibility of conceiving a "middle way", which uses the acknowledged power of assessment to control the content, emphases and quality of educational delivery, whilst recognising the need to retain the integrity of the principle of mass education—namely the aspiration to equip individuals with the moral awareness and skills needed to be effective participants in a mature democracy’ (Broadfoot, 1999, p. 23).

\section{REFERENCES}

Alluin, F. \& Do, C.L. (1996) L'usage des outils d'aide à l'évaluation dans l'enseignement primaire et secondaire [How are instruments to help teachers evaluation in primary and secondary schools used?] (Paris, ministère de l'Education nationale, Direction de l'Evaluation et de la Prospective).

Arendt, H. (1993) The crisis in education, in: Between Past and Future (Harmondsworth, Penguin Classics).

Barroso, J. (2000) Autonomie et mode de régulation locale dans le système éducatif [Autonomy and local regulation processes in the educational system], Revue française de pédagogie, 130, pp. 57-72.

Bidwell, L.E. (1965) The school as a formal organisation, in: J.G. MARch (Ed.) The Handbook of Organisations (Chicago, IL, Rand McNally).

Blanchet, R. (2000) La revalorisation du rôle des chefs d'établissements de l'enseignement secondaire, Rapport au Ministre de l'Education nationale [The reevaluation of the principal's role in secondary schools] (Paris, La Documentation Française).

Broadfoot, P. (1996) Education, Assessment and Society (Buckingham, Open University Press).

Broadfoot, P. (1999) The role of educational assessment in England and France, The Tocqueville Review, 20 (2), pp. 9-24.

BRoAdfoot, P. (2000) Un nouveau mode de régulation dans un système centralisé: l'Etat évaluateur [A new regulation method in a decentralized system: assessment by state], Revue française de pédagogie, 130, pp. 43-55.

Broadfoot, P.M. \& Osborn, M.J. (1993) Perceptions of Teaching: primary school teachers in England and France (London, Cassell).

Broccholichi S. \& van Zanten A. (1997) Espaces de concurrence et circuits de scolarisation. L’évitement des collèges publics d'un district de la région parisienne, [Competition and scholarisation: avoidance of public middle schools in the Paris area], Annales de la recherche urbaine, 75. 
Crahay, M. (2000) L'école peut-elle être juste et efficace? [Can schools be both just and efficient?] (Bruxelles, de Boeck).

Davies, J. \& Guppy, T. (1997) Globalization and educational reform in Anglo-American democracies, Comparative Education Review, 41 (4), pp. 435-459.

Debray, R. (1998, 3 March) Lettre Ouverte à M. le Ministre de l'Education [Open letter to the Minister of Education], Le Monde.

Demailly, L., Deubel, Ph., Gadrey, N. \& Verdière, J. (1998) Evaluer les établissements scolaires: enjeux, expériences, débats [Evaluating the schools: stakes, experiences, debates] (Paris, L’Harmattan).

Deschamps, M. (1998) Les Français et l’école [The French and their school], in: O. Duhamel \& Ph. Méchet (Eds) L'état de l'opinion [The state of opinion] (Paris, Seuil).

Dubet, F., Bergounioux, A., Duru-Bellat, M. \& Gauthier, R-F. (1999) Le collège de l'an 2000 [A middle school for the year 2000] (Paris, La Documentation Française).

Dubet, F. \& Duru-Bellat, M. (2000) L’hypocrisie scolaire [Educational Hypocrisy] (Paris, Seuil).

Duru-Bellat, M. (1996) De quelques effets pervers des pédagogies différenciées [Unexpected effects of individualisation of treaching], Education, 7, pp. 12-15.

Duru-Bellat, M. (2000) Social inequalities in the French education system: the joint effect of individual and contextual factors, Journal of Education Policy, 15 (1), pp. 33-40.

Duru-Bellat, M. \& Mingat, A. (1997) La constitution de classes de niveau dans les colleges [Ability grouping in French middle schools], Revue française de Sociologie, XXXVIII, pp. 759-790

Duru-Bellat, M. \& KiefFer, A. (2000) Inequalities in educational opportunities in France: educational expansion, democratization or shifting barriers? Journal of Education Policy, 15 (3), pp. 333-352.

Edwards, T. \& Whitty, G. (1994) Parental choice and school autonomy: the English Experience, Unicorn, 20 (1), pp. 25-34.

EdwARds, T. \& WhitTy, G. (1997) Specialization and selection in secondary education, Oxford Review of Education, 23 (1), pp. 5-15.

Emin, J. C. (1996) Les indicateurs pour le pilotage des collèges et des lycées [Indicators for monitoring middle and high schools], in: J. Vogler (Ed.) L'évaluation [Evaluation] (Paris, Hachette).

Finkelstein, N.D. \& GrubB, W.N. (2000) Making sense of education and training markets: lessons from England, American Educational Research Journal, 37 (3), pp. 601-632.

Fitz-GibBon, C. \& Stephenson, N.J. (1996) Inspecting Her Majesty’s Inspectors, Should Social Science and Social Policy Cohere?, Paper for the European Conference on Educational research, Seville, 25-28 September.

Gewirtz, S., Ball, S.J. \& Bowe, R. (1995) Markets, Choice and Equity in Education (Buckingham, Open University Press).

Gibson, A. \& Asthana, S. (1999) What's in a number? Research Papers in Education, 15 (2), pp. $133-153$.

Goldstein, H. (1997) Value added tables: the less than holy grail, Managing Schools Today, 6, pp. $18-19$.

Gorard, S. \& Fitz, J. (1998) The more things change... The missing impact of marketisation, British Journal of Sociology of Education, 19 (3), pp. 365-375.

Gorard, S. \& FITZ, J. (2000) Investigating the determinants of segregation between schools, Research Papers in Education (2), pp. 115-132.

Gorard, S. \& TAYlor, C. (2002) Market forces and standards in education: a preliminary consideration, British Journal of Sociology of Education, 23 (1), pp. 5-18.

GrisAy, A. (1993) Le fonctionnement des collèges et ses effets sur les élèves de $6^{\text {ème }}$ et $5^{\text {ème}}$, [The operating of middle schools and its effects on pupils from grade six and seven Les Dossiers d'Education et Formation, MEN-DEP, $\mathrm{n}^{\circ} 32$ [Education and Training Documents, Paris, Ministry of Education].

HaRmon, M. et al. 1997, Performance Assessment in IEA's Third International Mathematics and Science Study (Chestnut Hill, MA, TIMSS International Study Centre).

Hunter, J. (1991) Which school? A study of parents' choice of secondary school, Educational Research, 33 (1), pp. 31-41.

Inspection Générale de l'Administration de l'Education Nationale (IGAEN) General Inspection of Administration of National Education (1999) Rapport [Report] (Paris, La Documentation Française).

Joutard, Рh. \& ThÉlot, C. (1999) Réussir l'école [A successful school] (Paris, Seuil).

LaPointe, A.E., MeAd, N. \& PhilLips, G. (1999) A World of Differences: an international assessment of mathematics and science (Princeton, NJ, ETS).

MacBeath, J. (1999) Schools Must Speak for Themselves (London, Routledge).

Meuret, D. (1986) Le tableau de bord des collèges et des lycées, histoire d'un ajustement [Indicators for middle and high schools: a story of ajustment], Politiques et Management Publics, 4 (1), pp. 1-28.

Meuret, D. (1998) Intérêt, justice, laïcité [Interest, justice, secularity], Le Télémaque, $\mathrm{n}^{\circ}$ 14, Presses Universitaires de Caen, pp. 67-78. 
Meuret, D. \& Duru-Bellat, M. (2002) Vers de nouveaux modes de gouvernement des systèmes éducatifs? Les leçons des comparaisons internationales, Politiques et management public [Towards new processes of educational systems government: lessons from international comparisons], 20 (2), pp. 61-80.

Meuret, D., Broccholichi, S. \& Duru-Bellat, M. (2001) Autonomie et Choix des établissements scolaires: finalités, modalités, effets [Autonomy and choice of schools: what for, how and with which effects?] Cahiers de I'IREDU, n 62.

Milgrom, P. \& Roberts, J. (1992) Economics, Organisation and Management (Englewood Cliffs, NJ, Prentice-Hall). Ministè Re de L'É Ducation nationale (2002) Protocole d'accord relatif aux personnels de direction, Bulletin official de l'Education nationale, spécial number 1 [An agreement on school managers], 3 January (Paris, Ministry of Education).

Ministère de L'Éducation nationale, DPD (2001a) Note d'information 01-35 [Information note 01-35] (Paris, Ministry of Education).

Ministère de L'Éducation nationale, DPD (2001b) Note d'information 01-36 [Information note 0136] (Paris, Ministry of Education).

Ministère de L’Éducation nationale, DEP (1996) Note d'information 96-36 [Information note 96-36] (Paris, Ministry of Education).

MinTZBERG, H.T.F.(1973) The structuring of organisations: a synthesis of the research (Englewood Cliffs, NJ, Prentice Hall Inc).

Murphy, J. \& Beck, L.G. (1995) School Based Management as School Reform (Thousand Oaks, CA,

Corwin Press).

Noden, P. (2000) Rediscovering the impact of marketisation: dimensions of social segregation in England's secondary schools, 1994-1999, British Journal of Sociology of Education, 21 (3), pp. 371-390.

OAKLEY, A. (2002) Research evidence, knowledge management and educational practice: lessons for all? Paper for the High-level forum on Knowledge Management in Education and Learning, Oxford, 18-19 March.

OECD (1995) Education at a Glance (Paris, Organisation of Economic Cooperation and

Development). OECD (1998) Education at a Glance (Paris, Organisation of Economic

Cooperation and Development).

OECD (2001a) Knowledge and Skills for Life: first results from PISA 2000. Paris, Organisation of Economic Cooperation and Development).

OECD (2001b) Education at a Glance (Paris, Organisation of Economic Cooperation and

Development). OECD (2002) Education at a Glance (Paris, Organisation of Economic Cooperation and Development). OfSTED (2001) The National Literacy Strategy: the third year report, an evaluation by HMI (London, OfSTED).

Osborn, M., Broadfoot, P., Planel, C. \& Pollard, A. (1997) Social class, educational opportunity and equal entitlement: dilemmas of schooling in England and in France, Comparative Education, 33 (3), pp. 375-393.

Ravitch, D. (1999) Introduction, Brookings Paper in Education Policy, pp. 1-9.

Reynolds, D. \& Farrell, S. (1996) Worlds Apart? A review of international surveys of educational achievement involving England (London, OfSTED).

Robitaille, D.F. \& Garden, R.A. (1999) The IEA Study of Mathematics II (Oxford, Pergamon Press).

SAUNDERS, L. (1999) Who or what is self-evaluation for? School Effectiveness and School Improvement, 10 (4), pp. 414-430.

Scheerens, J. \&Bosker, R. (1997) The Foundations of Educational Effectiveness (Oxford,

Pergamon).

SchrieWER, J. (1997) L'éducation comparée: mise en perspective historique d’un champ de recherche [Comparative education: an historical view of a research field], Revue Française de pédagogie, 121, pp. 9-28.

Stoll, L. \& Myers, K. (Eds) (1997) No Quick Fixes (London, Falmer Press).

Trancart, D. (2003) Evolution de la ségrégation dans les collèges publics [Evolution of segregation in public middle schools], Revue Française de Pédagogie (forthcoming ).

West, A. \& Ingram, D. (2001) School admissions in England: cream-skimming and quasi-regulation, Paper for presentation at the AERA annual meeting, Seattle.

WRAGG, E.C. et al. (1999), The role of the headteacher in addressing the problem of incompetent teachers, Paper for AERA congress, Montreal. 